\title{
Cell-free DNA as a liquid biopsy for early detection of gastric cancer (Review)
}

\author{
ZHENG-BIN HUANG ${ }^{1}$, HAI-TAO ZHANG ${ }^{2}$, BENJAMIN YU $^{3}$ and DE-HUA YU ${ }^{4}$ \\ ${ }^{1}$ Department of Surgery, Hanchuan Renmin Hospital, Hanchuan, Hubei 431600; \\ ${ }^{2}$ Department of Gastrointestinal Surgery, The Second People's Hospital of Shenzhen, Shenzhen, \\ Guangdong 518037, P.R. China; ${ }^{3}$ Northwestern University Feinberg School of Medicine, Chicago, IL 60611, USA; \\ ${ }^{4}$ Shenzhen USK Bioscience Co., Ltd., Shenzhen, Guangdong 518110, P.R. China
}

Received April 17, 2020; Accepted September 17, 2020

DOI: $10.3892 / 01.2020 .12264$

\begin{abstract}
Gastric cancer (GC) is one of the most common malignant tumors with poor prognosis worldwide, mainly due to the lack of suitable modalities for population-based screening and early detection of this disease. Therefore, novel and less invasive tests with improved clinical utility are urgently required. The remarkable advances in genomics and proteomics, along with emerging new technologies for highly sensitive detection of genetic alterations, have shown the potential to map the genomic makeup of a tumor in liquid biopsies, in order to assist with early detection and clinical management. The present review summarize the current status in the identification and development of cell-free DNA (cfDNA)-based biomarkers in GC, and also discusses their potential utility and the technical challenges in developing practical cfDNA-based liquid biopsy for early detection of GC.
\end{abstract}

\section{Contents}

1. Introduction

2. Quantification of circulating cfDNA

3. Detection of genetic alteration of circulating tumor DNA (ctDNA)

4. Measurement of cfDNA methylation

5. Current challenges

6. Conclusion

Correspondence to: Dr De-Hua Yu, Shenzhen USK Bioscience Co., Ltd., 5th Floor, Building A, 2nd Jinmeiwei Industry Park, Guanlan High-Tech Park, Guanlan, Longhua, Shenzhen, Guangdong 518110, P.R. China

E-mail: derek.yu@uskbio.com

Key words: gastric cancer, liquid biopsy, cell-free DNA, circulating tumor DNA, methylation

\section{Introduction}

Despite significant progress being made in the prevention and treatment of gastric cancer (GC) in the past decades, GC is still one of the most concerning malignancies as the majority of patients are diagnosed at an advanced stage of disease. Globally, GC ranked fifth for cancer incidence and third for cancer deaths, accounting for 1.3 million estimated incident cases and 819,000 estimated deaths in 2015 (1). Geographically, GC is more prevalent in developing countries, with the majority of cases and deaths occurring in Eastern Asia, including China, Japan and Korea, followed by Central Europe, Eastern Europe and South America (2). Etiologically, GC is a multifactorial disease attributed to both host and environmental factors. Proposed risk factors for GC include Helicobacter pylori (H. pylori) infection, smoking, alcohol, obesity, salt intake, atrophic gastritis (AG), intestinal metaplasia (IM) and family history of GC. The current therapy for GC includes surgery, chemotherapy, radiotherapy, VEGFR (ramucirumab) and targeted therapy against HER2 (trastuzmab) (3). The overall outcome of GC is largely associated with the stage of the disease at diagnosis. For early GC limited to the mucosa and submucosa, the 5-year survival rate is $>90 \%(4,5)$. However, due to the lack of distinguishable symptoms at early stages and effective mass screening programs worldwide, the majority of GC cases are typically detected at stage IIIA-IV, with an estimated 5-year survival rate of $<30 \%$ and a median survival of 12 months $(4,5)$.

To date, four GC screening methodologies have been implemented in clinical settings: $H$. pylori serology, serum pepsinogen (PG) testing, indirect upper gastrointestinal series (UGIS) and endoscopy. Since the 1960s, population-based GC screening programs in several high-prevalence nations such as Japan and Korea have achieved significantly improved survival and cure rates using the above methods. These programs demonstrate the effectiveness of mass screening for GC (6-8). However, each of these screening tools has its limitations. For instance, $H$. pylori serology is unable to detect premalignant lesions, such as longstanding AG and IM. Therefore, H. pylori serology alone is not useful as a screening test for GC (9). The combination of upper endoscopy with pathological biopsy examination is the primary screening technique in the 
majority of these programs and the gold standard for confirmation of diagnosis (10). In general, endoscopy is superior to UGIS in sensitivity and cost-effectiveness for detecting early GC (11-13). However, endoscopy is an invasive technique that has infrequent but serious complications, and its utility depends largely on the skill of the endoscopist (14). Therefore, the use of endoscopy in mass-screening programs in low-prevalence and low-income countries is impractical and likely to be associated with low participation rates. Currently, the only non-invasive test for GC detection in the clinical setting is the PG assay (15). Changes in serum PG levels reflect the function of the gastric mucosa. Decreased PGI levels and PGI/PGII ratio are indicators of atrophic changes in the gastric corpus. PG tests can detect gastric mucosal atrophy with a sensitivity of 66.7-84.6\% and a specificity of 73.5-87.1\% (16,17). However, PG assay's sensitivity for GC detection ranges from 36.8 to $62.3 \%(18,19)$, which is too low to be acceptable for population-based screening. Therefore, new assays with improved sensitivity, specificity and cost-effectiveness are needed.

Recent advances in genetic testing, such as next-generation sequencing (NGS) and digital PCR, and bioinformatics have accelerated the research on liquid biopsy greatly, which have high potential to change the clinical management of patients with cancer. Meanwhile, considerable efforts have been made to identify novel, early-stage GC biomarkers with potential utility in clinical liquid biopsy testing. Such biomarkers include cell-free DNA (cfDNA), cell-free RNA (cfRNA), proteins, autoantibodies, circulating tumor cells (CTCs), cancer-derived extracellular vesicles (EVs) and metabolites. A number of comprehensive reviews were recently published on CTCs, proteomics, cfRNA biomarkers, exosomes and EVs in GC $(20,21)$. The current review provides an overview of the recent advances in the early detection of GC using liquid biopsy, with a focus on cfDNA, and their origin and mechanism of release into the bloodstream, as well as their potential utility in clinical practice (Fig. 1).

\section{Quantification of circulating cfDNA}

cfDNA is circulating extracellular DNA existing in the blood serum or plasma, synovial fluid, cerebrospinal fluid and other body fluids. Physiological events producing cfDNA include cellular apoptosis, secretion, micrometastasis and necroptosis (22). In patients with cancer, the plasma cfDNA levels are 2-3-fold higher than those in normal healthy groups (23), suggesting its potential as a complementary biomarker for cancer detection, as well as an indicator of prognosis and therapeutic response. As shown in Table I, a prospective study quantified the cfDNA levels in serum samples from patients with benign or malignant gastrointestinal tract disease using a radioimmunoassay, and it showed that the cfDNA levels in patients with malignant diseases were significantly higher than those of patients with benign diseases (24). Consistently, Sai et al (25) reported that increased plasma total cfDNA in patients with GC could be detected compared with the undetectable levels of healthy controls (Table I). The authors measured the short and long forms of $\beta$-actin in plasma samples from patients with GC and healthy controls by quantitative PCR (qPCR), and found that the cfDNA concentration in patients with GC was significantly higher. These studies suggest the potential use of serum cfDNA concentration assay to detect GC.

There are various methods for quantitative cfDNA detection, but their efficiency is limited by sample preparation and assay procedures. To address this issue, Park et al (26) developed an Alu-qPCR assay for measuring cfDNA concentrations, which demonstrated better sensitivity and reproducibility compares with other technologies, based on Ultraviolet-visible (UV-Vis) spectrophotometry or the PicoGreen fluorophore. Applying this assay, the cfDNA levels were compared between patients with GC and those of age-matched healthy controls, and found that the mean levels of plasma cfDNA were higher in the GC group than in the control group (Table I). To understand the dynamics of cfDNA levels pre- and post-surgery, Kim et al (27) measured the plasma cfDNA levels of patients with GC and healthy controls by qPCR. The samples of the patients with GC were collected before and $24 \mathrm{~h}$ after surgery. The results showed that average cfDNA levels were increased in patients with GC compared with those of healthy controls, and there was a positive dose-dependent association with more advanced cancer staging. Meanwhile, the levels of cfDNA in the 24-h-post-surgery group decreased significantly, thus supporting the utility of using cfDNA to monitor disease severity and therapeutic efficacy.

Recently, Qian et al (28) investigated cfDNA levels in serum samples from 124 patients with GC, 64 patients with benign gastric disease (BGD; namely gastric adenoma) and 92 healthy controls using the Alu-qPCR assay. The results showed that cfDNA levels were significantly higher in patients with GC compared with those with BGD or in healthy controls $(\mathrm{P}<0.05)$. Further statistical analysis showed that serum cfDNA levels in the GC group were significantly associated with advanced staging (III-IV) and tumor size $(>5 \mathrm{~cm}$ ), but not with sex, age or tumor location. cfDNA was also more sensitive in the detection of stage-I GC than conventional tumor biomarkers, including carcinoembryonic antigen (CEA), carbohydrate antigen (CA)-19-9, CA50 and CA72-4, suggesting that cfDNA assays may be able to replace current protein tumor biomarkers for cancer detection.

Since the measurement of cfDNA levels does not require any prior knowledge of genetic alterations in tumor tissue, this test could be highly useful in non-invasive assays for early GC detection. However, the application of cfDNA quantification alone for early cancer diagnosis is limited by several obstacles: i) Circulating cfDNA is unstable and its kinetics has not yet been well defined, which may affect assay robustness and standardization; ii) cfDNA levels cannot differentiate cancer type or tissue of origin; iii) cfDNA testing is relatively nonspecific, as numerous patients with non-cancer conditions, such as inflammatory disease, infections and cardiovascular disease, and even healthy individuals after exercise, show elevated cfDNA levels $(29,30)$. Therefore, it is expected that the combined detection of cfDNA levels with other markers may achieve improved clinical performance.

\section{Detection of genetic alteration of circulating tumor DNA (ctDNA)}

Genetic alterations such as mutations, rearrangement and amplification of driver genes result in tumorigenesis. Recent 


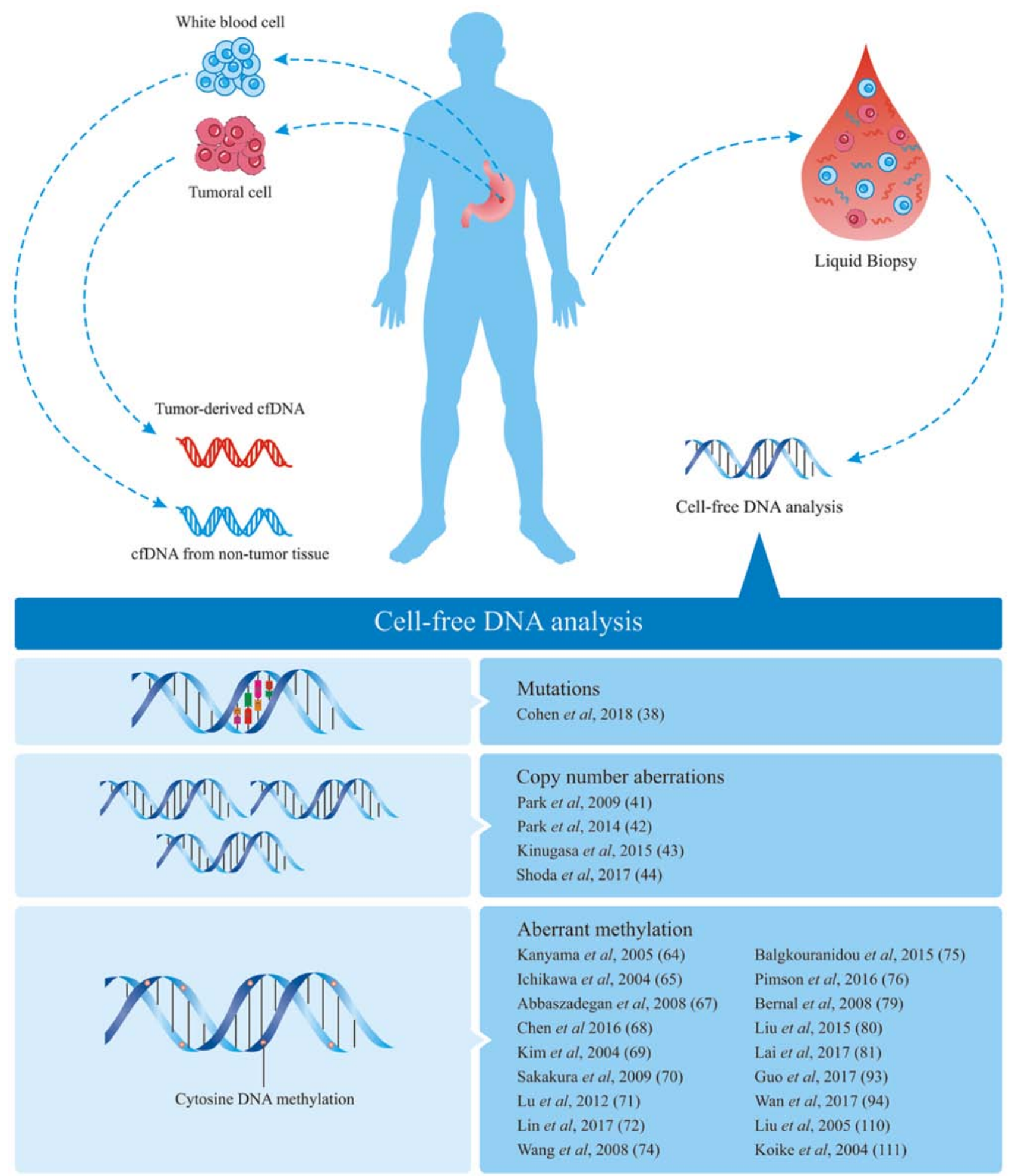

Figure 1. Overview of cfDNA in the early detection of GC through liquid biopsy. Circulating cfDNA provides a variety of clinically informative components. GC-associated changes can be detected through the analysis of cfDNA, including i) mutations; ii) copy number variants of genes; and iii) aberrations in DNA methylation. cfDNA, cell-free DNA; GC, gastric cancer.

advancements in NGS techniques have identified various nucleotide mutations associated with GC (Table II). The top mutated genes showing higher mutation frequency were TP53, TTN, MUC16, CDH1, KMT2C and MLH1 (31-33). In 1977, Leon et al (34) reported that numerous patients with cancer had elevated circulating cfDNA, and found that this DNA was tumor derived. Since, scientists focused their attention on the content of ctDNA. Some of the aberrant DNA shed into the blood by cancer cells, such as EGFR and KRAS mutations, can be potential biomarkers. Previous studies have demonstrated the detectability of mutant DNA released from tumor tissues. In fact, ctDNA analysis has emerged as an additional diagnostic tool to guide clinical management of certain cancer types including lung cancer and colon cancer $(35,36)$. However, 
Table I. cfDNA as biomarker for detection of gastric cancer.

Diagnostic value

\begin{tabular}{|c|c|c|c|c|c|c|}
\hline cfDNA & Biomarker candidate & Sample type & Method & Sensitivity & Specificity & (Refs.) \\
\hline \multirow[t]{4}{*}{ cfDNA } & cfDNA levels & Serum & Radioimmuno assay & $\begin{array}{l}\text { Mean concentration of } \\
412 \text { and } 118 \mathrm{ng} / \mathrm{ml} \\
\text { respectively }(\mathrm{P}<0.01)\end{array}$ & & (24) \\
\hline & & Plasma & qPCR & $\begin{array}{l}\text { By } 102 \mathrm{bp} \beta \text {-actin assay, } \\
\mathrm{GC}=5.71 \mathrm{ng} / \mathrm{ml} \text {, } \\
\mathrm{HC}=3.20 \mathrm{ng} / \mathrm{ml}(\mathrm{P}=0.03) \\
\text { By } 253 \mathrm{bp} \beta \text {-actin assay, } \\
\mathrm{GC}=0.470 \mathrm{ng} / \mathrm{ml}, \\
\mathrm{HC}=0.212 \mathrm{ng} / \mathrm{ml}(\mathrm{P}<0.0001)\end{array}$ & & (25) \\
\hline & & Plasma & Alu81-qPCR & $75 \%(41 / 54)$ & $63 \%(37 / 59)$ & (26) \\
\hline & & Plasma & $\begin{array}{l}\text { Measurement of } \\
\text { cfDNA } \\
\text { concentration }\end{array}$ & $96.67 \%(29 / 30)$ & $94.11 \%(32 / 34)$ & (27) \\
\hline
\end{tabular}

cfDNA, cell-free DNA; qPCR, quantitative PCR; bp, base pair.

the use of ctDNA for early cancer detection is complicated by the generally low abundance of ctDNA in early-stage cancer and the technical challenges in its detection.

Applying the droplet digital PCR (ddPCR) assay, which is currently the most sensitive method, Bettegowda et al (37) evaluated ctDNA in 640 plasma samples from patients with various cancer types and stages. ctDNA was detected in $>75 \%$ of patients with several advanced cancer types, including melanoma, and pancreatic, breast, hepatocellular, ovarian, colorectal, bladder, gastroesophageal, and head and neck cancer. In patients with localized tumors, ctDNA was detectable only in a subset of patients with gastroesophageal cancer $(57 \%)$, colorectal cancer (CRC) $(73 \%)$, pancreatic cancer $(48 \%)$ and breast adenocarcinoma (50\%). When KRAS mutations were tested for in ctDNA in an additional panel of 206 patients with metastatic CRC, the sensitivity and specificity of detection were 87.2 and $99.2 \%$, respectively. These results indicate that the detectability of ctDNA is affected by cancer type and stage.

Recently, Cohen et al (38) developed a blood-based test (CancerSEEK) and investigated its utility in the early detection of eight common cancer types, such as ovarian, liver, stomach, pancreatic, esophageal, colorectal, lung and breast cancer. The above blood test couples targeted parallel sequencing of ctDNA with eight known protein biomarkers using a panel of 61 amplicons in 16 genes, including TP53, $K R A S, P I K 3 C A, C T N N B 1$ and $A P C$. The authors applied this assay to 1,005 patients with clinically detected stage I-III cancer, and the method yielded $70 \%$ of median positivity for all eight cancer types tested and $>99 \%$ specificity for healthy controls. Using this assay, the authors were also able to track the cancer origin to two possible sites in $\sim 80 \%$ of patients. As shown in Table III, GC samples were included in this study, and mutations of a number of driver genes were detected. This study suggests the divergent utility of a single test in detecting multiple early-stage cancer types.
In addition to mutations, the copy number variants of numerous genes such as $c-M Y C$ and HER2 were also identified in GC by genome-wide profiling $(39,40)$. Applying a qPCR assay, Park et al (41) measured the $M Y C / G A P D H$ ratio in plasma samples from patients with GC and cancer-free individuals. This showed that the mean ratio of $M Y C / G A P D H$ in plasma was significantly increased in GC compared with that in healthy controls $(\mathrm{P}<0.001)$. Another study compared the plasma levels of HER2 and MYC genes in patients with GC, gastric adenoma, gastritis or no disease with those in matched tissue samples by reverse transcription-qPCR (42). The results indicated that the $H E R 2 / H B B$ and $M Y C / H B B$ ratios in tissue and plasma from patients with GC were significantly increased compared with those in gastritis tissue and cancer-free individuals. Similarly, Kinugasa et al (43) detected increased HER2 in ctDNA from serum samples in patients with GC by ddPCR. Recently, Shoda et al (44) investigated the HER2 gene levels in plasma samples of patients with GC and healthy controls using ddPCR. The results showed that the preoperative plasma $H E R 2$ ratio (normalized with an internal control) correlated with HER2-positivity status in the tumor $(\mathrm{P}<0.001)$ (Table III). Of note, although the increased levels of circulating HER2 and $c-M Y C$ genes were detectable in GC, their potential utility in early diagnosis would be limited by their low positivity rates in patients with GC.

\section{Measurement of cfDNA methylation}

DNA modifications such as 5-methylcytosine (5-mC) and 5-hydroxymethylcytosine $(5-\mathrm{hmC})$ could serve as ideal biomarkers for cancer diagnosis. The 5-mC remodeling of DNA has been reported to be involved in cancer initiation, progression and therapeutic response (45). Except for 5-mC, a previous study by $\mathrm{Li}$ et al (46) showed that 5 -hmC from circulating cfDNA was highly predictive of colorectal and gastric cancer, and was superior to conventional biomarkers 
Table II. Type and frequency of mutations implicated in gastric cancer.

\begin{tabular}{|c|c|c|c|c|}
\hline No. of patients & Method & Top mutated genes & Mutation frequency $(\%)$ & (Refs.) \\
\hline \multirow[t]{9}{*}{74} & WES & TP53 & 48 & $(31)$ \\
\hline & & TTN & 37 & \\
\hline & & MUC16 & 15 & \\
\hline & & ABCA13 & 12 & \\
\hline & & SYNE1 & 12 & \\
\hline & & DCHS2 & 11 & \\
\hline & & HMCN1 & 11 & \\
\hline & & OBSCN & 11 & \\
\hline & & ROBO1 & 11 & \\
\hline \multirow[t]{11}{*}{63} & WES & TP53 & 48 & $(32)$ \\
\hline & & TTN & 37 & \\
\hline & & MUC16 & 14 & \\
\hline & & ABCA13 & 13 & \\
\hline & & DCHS2 & 13 & \\
\hline & & DNAH11 & 11 & \\
\hline & & HMCN1 & 11 & \\
\hline & & LAMA1 & 11 & \\
\hline & & PCLO & 11 & \\
\hline & & ROBO1 & 11 & \\
\hline & & SYNE1 & 11 & \\
\hline \multirow[t]{11}{*}{43} & WES & TP53 & 41 & $(33)$ \\
\hline & & CDH1 & 26 & \\
\hline & & KMT2C & 24 & \\
\hline & & MLH1 & 18 & \\
\hline & & SMAD4 & 15 & \\
\hline & & GNAS & 15 & \\
\hline & & CDKN2A & 12 & \\
\hline & & RPL5 & 12 & \\
\hline & & TAF1 & 12 & \\
\hline & & SETD2 & 12 & \\
\hline & & PTEN & 12 & \\
\hline
\end{tabular}

WES, whole-exome sequencing; TP53, tumor protein p53; TTN, Titin; mucin 16, cell surface associated; ABCA13, ATP binding cassette subfamily A member 13; DCHS2, dachsous cadherin-related 2; SYNE1, spectrin repeat containing nuclear envelope protein 1; HMCN1, hemicentin 1; OBSCN, obscurin, cytoskeletal calmodulin and titin-interacting RhoGEF; ROBO1, roundabout guidance receptor 1; LAMA1, laminin subunit alpha 1; PCLO, piccolo presynaptic cytomatrix protein; CDH1, cadherin 1; KMT2C, lysine methyltransferase 2C; MLH1, mutL homolog 1; SMAD4, SMAD family member 4; GNAS, GNAS complex locus; CDKN2A, cyclin dependent kinase inhibitor 2A; RPL5, ribosomal protein L5; TAF1, TATA-box binding protein associated factor 1; SETD2, SET domain containing 2, histone lysine methyltransferase; PTEN, phosphatase and tensin homolog.

and comparable to 5-hmC biomarkers from tissue biopsies. Hypermethylation of promoter $\mathrm{CpG}$ islands in tumor suppressor genes plays a crucial role in carcinogenesis (47-49). Eyvazi et al (50) verified the promoter methylation of EphA5, HS3ST2 and CDH11 genes in patients with GC using paraffin-embedded tissue sections. Recently, cfDNA in blood plasma has become a promising cancer biomarker for early diagnosis (51). The abnormal methylation of a large number of genes has been demonstrated to have utility for non-invasive detection of cancer in plasma or serum samples (52-54). Among them, Septin 9 gene methylation, detectable as hypermethylated Septin 9 DNA fragments in blood plasma, is a front-runner for the clinical screening of CRC (55). Septin 9, a member of the Septin family, was originally identified in myeloid neoplasia (56). It functions as a tumor suppressor gene in multiple cancer types (57). Consequently, several assay kits have been developed to detect methylated Septin 9. Epi proColon, the first commercial methylated Septin 9 assay, has been approved by the USA Food and Drug Administration (FDA) for average-risk patients over the age of 50 years, and has also been approved in Europe and China (58). Meta-analysis of existing clinical data showed that the assay's sensitivity and specificity were 71 and $92 \%$, respectively, demonstrating its reliability for CRC detection $(59,60)$. In 2016, a blood test that 
Table III. ctDNA as biomarker for detection of gastric cancer.

\begin{tabular}{|c|c|c|c|c|c|c|}
\hline \multirow[b]{2}{*}{ Type } & \multirow[b]{2}{*}{ Biomarker candidate } & \multirow[b]{2}{*}{ Sample type } & \multirow[b]{2}{*}{ Method } & \multicolumn{2}{|c|}{ Diagnostic value, \% (n) } & \multirow[b]{2}{*}{ (Refs.) } \\
\hline & & & & Sensitivity & Specificity & \\
\hline \multirow[t]{7}{*}{ ctDNA } & $\begin{array}{l}\text { Gene mutations (TP53, } \\
\text { KRAS, PIK3CA, CTNNB1, } \\
\text { APC, PPP2R1A }\end{array}$ & Plasma & NGS & $72(49 / 68)$ & $99(805 / 812)$ & (38) \\
\hline & MYC gene copy number & Plasma & qPCR & $75.4(43 / 57)$ & $76.9(60 / 79)$ & (41) \\
\hline & $\begin{array}{l}\text { (MYC/GAPDH ratio } \\
\text { and MYC/HBB ratios) }\end{array}$ & Plasma & qPCR & $\begin{array}{l}72.8(59 / 81) \text { for } \\
\text { MYC }>2.725\end{array}$ & $77.7(80 / 103)$ & $(42)$ \\
\hline & $\begin{array}{l}\text { HER } 2 \text { and MYC gene } \\
\text { copy number (HER } 2 / H B B \\
\text { and MYC/HBB ratios) }\end{array}$ & Plasma & qPCR & $\begin{array}{l}69.1(56 / 81) \text { for } \\
\text { both HER2>2.0 } \\
\text { and MYC }>2.725\end{array}$ & $92.2(95 / 103)$ & \\
\hline & $\begin{array}{l}\text { HER2 gene copy } \\
\text { number }\end{array}$ & Plasma & qPCR & $\begin{array}{l}87.7(71 / 81) \text { for } \\
\text { HER } 2>2.0\end{array}$ & $64.1(66 / 103)$ & \\
\hline & & Tissue and serum & ddPCR & $29.2(7 / 24)$ & & (43) \\
\hline & & Plasma & $\mathrm{qPCR}$ & $\begin{array}{l}\text { For discovery: } \\
53.9(7 / 13) \\
\text { For validation: } \\
66.7(2 / 3)\end{array}$ & $\begin{array}{l}\text { For discovery: } \\
96.7(29 / 30) \\
\text { For validation: } \\
100(22 / 22)\end{array}$ & (44) \\
\hline
\end{tabular}

TP53, tumor protein p53; KRAS, kirsten rat sarcoma viral oncogene; PIK3CA, phosphatidylinositol-4,5-bisphosphate 3-kinase, catalytic subunit alpha; CTNNB1, catenin beta-1gene; APC, adenomatous polyposis coli gene; PPP2R1A, protein phosphatase 2 regulatory subunit $\alpha$; GAPDH, glyceraldehyde 3-phosphate dehydrogenase; HBB, hemoglobin beta; HER2, human epidermal growth factor receptor 2; NGS, Next generation sequencing; ddPCR, digital droplet PCR.

detects circulating methylated Septin 9 DNA was approved by the FDA to provide an alternative screening modality (61), thus paving the way for the development of a new generation of liquid biopsy tests for early cancer detection.

Besides Septin 9, there is increasing evidence demonstrating that many other hypermethylated genes, including Reprimo, Rassf1A, CDH1, CDKN2A, MLH1, RUNX3, APC and $p 16$, can be differentially detected in plasma or serum samples of patients with GC (Table IV). Among them, p16 gene hypermethylation in GC has been extensively studied. p16 is a cell-cycle regulator that arrests cells in $G_{1}$ phase by inhibiting cyclin D-dependent protein kinase (CDK)4 and CDK6 (62). It functions as a tumor suppressor and can be inactivated by hypermethylation in the gene-promoter region (63). Kanyama et al (64) investigated the promoter methylation status of the p16 gene in paired tumor and serum samples from patients with GC. p16 hypermethylation was found in primary GC samples but in none of the corresponding gastric mucosae. Consistently, Ichikawa et al (65) reported that hypermethylation of the promoter region in the p16 and E-cadherin genes was detected in serum DNA samples from patients with GC, but not from healthy volunteers. Recently, Guo et al (66) detected promoter methylation of the p16 gene in peripheral blood samples from patients with GC and healthy controls using methylation-specific PCR (MSP) analysis, and found that the ratio of methylated p16 was significantly higher in $\mathrm{GC}$ samples compared with the control group $(\mathrm{P}<0.01)$. However, the reported ratios of circulating p16 methylation in GC vary remarkably across different studies (67). Thus, further validations are needed to determine whether the variation in positive methylation ratios is due to assay aberrations or primary sample differences.

Besides p16, Runt-related transcription factor 3 (RUNX3) has also been reported as a candidate tumor suppressor in GC (68). Hypermethylation of $R U N X 3$ $\mathrm{CpG}$ islands was observed in GC cell lines and primary gastric carcinoma, with significantly higher ratios than in non-malignant gastric disorders (69). Consistently, high levels of methylated $R U N X 3$ sequences were also detected in the peripheral circulation of patients with GC. The $R U N X 3$ methylation index was concordant with cancer stage, histology, and lymphatic and vascular invasion, and was more sensitive than CEA as a biomarker (70). Applying a real-time MSP assay, Lu et al investigated RUNX3 methylation levels in serum samples from normal individuals without any gastric lesions or $H$. pylori infection, patients with benign lesions and patients with GC (71). Notably, the serum detection of RUNX3 methylation was negative in almost all benign and normal samples, except for two patients who had severe dysplasia. However, circulating methylated $R U N X 3$ was detected in almost all patients with GC who had detectable RUNX3 methylation in tissue samples with significant accordance $(\mathrm{k}=0.887$; $\mathrm{P}<0.001)$ (71). Recently, Lin et al (72) measured the methylation status of three selected genes in blood samples of patients with GC and precancerous lesions using an MSP assay, and found that the methylation rate of $Z I C 1$, HOXD10 and RUNX3 increased significantly during the progression of gastric carcinogenesis. For predicting GC and intraepithelial neoplasia, the combined detection of 
Table IV. Methylated DNA as biomarker for detection of gastric cancer.

\begin{tabular}{|c|c|c|c|c|c|c|}
\hline \multirow[b]{2}{*}{ cfDNA } & \multirow[b]{2}{*}{ Biomarker candidate } & \multirow[b]{2}{*}{ Sample type } & \multirow[b]{2}{*}{ Method } & \multicolumn{2}{|c|}{ Diagnostic value, \% (n) } & \multirow[b]{2}{*}{ (Refs.) } \\
\hline & & & & Sensitivity & Specificity & \\
\hline \multirow[t]{25}{*}{ MethyDNA } & P16 & Serum & MSP & $26(6 / 23)$ & $100(16 / 16)$ & (64) \\
\hline & & Serum & MSP & $18(20 / 109)$ & $100(10 / 10)$ & $(65)$ \\
\hline & & Blood & MSP & $72.6(77 / 106)$ & $94.4(17 / 18)$ & (93) \\
\hline & & Serum & MSP & $51.9(28 / 54)$ & $100(30 / 30)$ & (98) \\
\hline & & Plasma & MSP/HPLC & $14.3(12 / 84)$ & $100(15 / 15)$ & $(110)$ \\
\hline & & Serum & MSP & $26.9(14 / 52)$ & $100(29 / 29)$ & $(67)$ \\
\hline & & Serum & MSP & $22(9 / 41)$ & $100(10 / 10)$ & $(111)$ \\
\hline & P16/E-Cadherin & Serum & MSP & $37(40 / 109)$ & $100(10 / 10)$ & $(65)$ \\
\hline & E-Cadherin & Serum & MSP & $24(26 / 109)$ & $100(10 / 10)$ & \\
\hline & & Serum & MSP & $22(9 / 41)$ & $100(10 / 10)$ & $(111)$ \\
\hline & p16/E-cadherin/RARbeta & Serum & MSP & $44(18 / 41)$ & $100(10 / 10)$ & \\
\hline & RUNX3 & $\begin{array}{l}\text { Tissues and } \\
\text { cell lines }\end{array}$ & MSP & $64(48 / 75)$ & & (69) \\
\hline & & Serum & rt-MSP & $70.8(143 / 202)$ & $99.8(848 / 850)$ & $(71)$ \\
\hline & & Serum & qMSP & 95.5 & 62.5 & (70) \\
\hline & & Plasma & MSP & $42.7(56 / 131)$ & $100(34 / 34)$ & (72) \\
\hline & $\begin{array}{l}\text { Plasma ZIC1, HOXD10 } \\
\text { and RUNX3 }\end{array}$ & Plasma & MSP & 91.6 & 50.0 & \\
\hline & Zic1 & Plasma & MSP & $69.5(91 / 131)$ & $100(34 / 34)$ & \\
\hline & RASSF1A & Serum & MSP & $34(16 / 47)$ & $100(30 / 30)$ & (74) \\
\hline & & Serum & MSP & $68.5(50 / 73)$ & $100(20 / 20)$ & $(75)$ \\
\hline & & Plasma & MSP & $83.2(84 / 101)$ & $94.55(191 / 202)$ & (76) \\
\hline & PCDH10 & Plasma & MSP & $94.1(95 / 101)$ & $97.03(142 / 202)$ & \\
\hline & Reprimo & Plasma & MSP & $95.3(41 / 43)$ & $90.3(28 / 31)$ & (79) \\
\hline & & Plasma & MSP & $86.3(44 / 51)$ & $97.6(48 / 49)$ & $(81)$ \\
\hline & & Plasma & MSP & $62(31 / 50)$ & $100(30 / 30)$ & (80) \\
\hline & hMLH1 & Plasma & MSP & $48(24 / 50)$ & $96.7(29 / 30)$ & \\
\hline
\end{tabular}

P16, Cyclin-dependent kinase inhibitor 2A, multiple tumor suppressor 1; E-Cadherin, epithelial cadherin; RARbeta, retinoic acid receptor beta; RUNX3, Runt-related transcription factor 3; ZIC1, zinc finger of the cerebellum 1; RASSF1A, Ras association domain-containing protein 1; PCDH10, protocadherin-10 gene; hMLH1, MutL homolog 1; MSP, methylation-specific polymerase chain reaction; HPLC, high performance liquid chromatography.

these three genes showed a synergistic effect compared with that of testing a single biomarker.

Ras-association domain family $1 \mathrm{~A}(R A S S F 1 A)$ is a putative tumor suppressor gene, which is often silenced by hypermethylation of its promoter region in a number of human tumors such as GC (73). Previous studies conducted by Wang et al (74) and Balgkouranidou et al (75) reported that RASSF1A methylation was detected in the serum samples of patients with GC, but not in the healthy control samples $(\mathrm{P}<0.001)$. Recently, Pimson et al (76) investigated the promoter methylation statuses of RASSF1A and PCDH1O (another tumor suppressor gene in the protocadherin family) in GC. The authors found that hypermethylation of $\mathrm{PCDH} 10$ and $R A S S 1 A$ was detectable in plasma samples from patients with GC, and aberrant $P C D H 10$ and RASSF1A promoter methylation in plasma DNA was associated with worse clinical outcome.
Reprimo $(R P R M)$ is another tumor suppressor gene involved in the development of numerous malignant tumors, including GC (77,78). Bernal et al (79) evaluated the DNA methylation patterns of 24 genes by MSP in primary tissues from patients with GC. In $>50 \%$ of cases, hypermethylation was detected in $\geq 1$ of 11 genes, including APC,SHP1, E-cadherin, ER, Reprimo, SEMA3B, 3OST2, p14,p15, DAPK and $p 16$. The most frequently hypermethylated genes were further evaluated in primary tissues and plasma samples from prospectively collected GC cases, as well as in plasma samples from asymptomatic age- and gender-matched controls (which formed the validation group). The results confirmed a high methylation frequency of seven genes (namely, $A P C, S H P 1, E$-cadherin, ER, Reprimo, SEMA3B and 3OST2) in GC. Notably, the prevalence of Reprimo methylation was significantly higher in GC tumor and plasma samples than in asymptomatic control samples $(\mathrm{P}<0.001)$. In another study $(80)$, the DNA methylation 
Table V. Methyated genes with limited sample sizes and method variants.

Diagnostic value, $\%(\mathrm{n})$

\begin{tabular}{|c|c|c|c|c|c|c|}
\hline Type & Biomarker candidate & Sample type & Method & Sensitivity & Specificity & (Refs.) \\
\hline \multirow[t]{16}{*}{ MethyDNA } & Zic1 & Plasma & MSP & $60.6(63 / 104)$ & $100(20 / 20)$ & (83) \\
\hline & RASSF10 & Serum & BSP & $81.71(67 / 82)$ & $89.5(85 / 95)$ & (84) \\
\hline & RNF180 & Plasma & q-MSP & $56(18 / 32)$ & $100(64 / 64)$ & $(85)$ \\
\hline & SFRP1 & Serum & MSP & $30.95(13 / 42)$ & $93.2(41 / 44)$ & (86) \\
\hline & IRX1 & Plasma & MSP & $73.3(11 / 15)$ & $90(9 / 10)$ & (112) \\
\hline & CYP26B1+KCNA4 & Serum & MSP & 91.3 & 92.1 & (113) \\
\hline & SLC19A3 & Plasma & MSRED-qPCR & $85(17 / 20)$ & $85(17 / 20)$ & (114) \\
\hline & FAM5C/MYLK & Serum & MSP & $77.6(45 / 58)$ & $90(27 / 30)$ & (115) \\
\hline & ATP4B & Plasma & MSP & $64(16 / 25)$ & $100(9 / 9)$ & (116) \\
\hline & XAF1 & Serum & rt-MSP & $83.9(141 / 168)$ & $94.3(83 / 88)$ & (117) \\
\hline & SOX17 & Serum & MSP & $58.9(43 / 73)$ & $100(20 / 20)$ & (118) \\
\hline & SPG20 & Blood & MSP & $48.8(20 / 41)$ & $100(21 / 21)$ & (119) \\
\hline & FLNC/THBS1/ & Serum & q-MSP & FLNC: 67 (55/82), & FLNC: 93.0 (80/86), & $(120)$ \\
\hline & UCHL1/DLEC1 & & & $\begin{array}{l}\text { THBS1: } 63.4 \text { (52/82), } \\
\text { UCHL1: } 56.1(46 / 82) \text {, } \\
\text { DLEC1: } 80.5 \text { (66/82), }\end{array}$ & $\begin{array}{l}\text { THBS1: } 94.2(81 / 86) \text {, } \\
\text { UCHL1: } 89.5(77 / 86) \text {, } \\
\text { DLEC1: } 93.0(80 / 86)\end{array}$ & \\
\hline & OSR2/VAV3/PPFIA3 & Serum & MSP & $\begin{array}{r}\text { OSR2: } 62.5(30 / 48), \\
\text { VAV3: } 45.8(22 / 48), \\
\text { PPFIA3: } 56.3(27 / 48), \\
\text { Combined: } 83.3(40 / 48)\end{array}$ & $\begin{array}{r}\text { OSR2: } 92(23 / 25), \\
\text { VAV3: } 100(25 / 25), \\
\text { PPFIA3: } 96(24 / 25), \\
\text { Combined: } 88(22 / 25)\end{array}$ & (121) \\
\hline & TFPI2 & Tissue & q-MSP & 68 & 83 & (122) \\
\hline
\end{tabular}

RASSF10, Ras-association domain family 10; RNF180, ring finger protein 180; SFRP1, secreted frizzled-related protein 1; IRX1, iroquois homeobox protein 1; CYP26B1, cytochrome P450 26B1; KCNA4, potassium voltage-gated channel subfamily A member 4; SLC19A3, solute carrier family 19 member 3; FAM5C, family with sequence similarity 5, member C; MYLK, myosin light chain kinase; ATP4B, ATPase H+/K+ transporting beta subunit; XAF1, XIAP-associated factor 1; SOX17, a member of the Sox family of transcription factors; SPG20, spastic paraplegia-20; FLNC, filamin-C; THBS1, thrombospondin 1; UCHL1, ubiquitin carboxy-terminal hydrolase L1; DLEC1, deleted in lung and esophageal cancer1; OSR2, protein odd-skipped-related 2; VAV3, guanine nucleotide exchange factor; PPFIA3, PTPRF-interacting protein alpha-3; TFPI2, tissue factor pathway inhibitor 2 .

statuses of the Reprimo and $h M L H 1$ genes in tissue and plasma samples of patients with GC, dysplasia, chronic AG and normal controls were investigated by MSP. The results showed that plasma hypermethylation of Reprimo was detectable in GC, AG and dysplasia, but not in normal controls. Meanwhile, methylated $h M L H$ was also detected in a higher percentage of GC and dysplasia samples compared with that of normal controls. Consistently, Lai et al (81) examined Reprimo gene methylation in GC tissues and plasma samples by bisulfite sequencing, and found that the Reprimo gene-promoter region was hypermethylated in GC tissues, plasma and cell samples. This was correlated with a decrease in Reprimo gene expression, thus supporting the potential utility of Reprimo methylation as a diagnostic biomarker for GC.

Of note, there is obvious heterogeneity in gene methylation frequencies between different studies, which might be attributable to differences in samples size, technique variations and geographical differences. To obtain a better understanding of this variance, Hu et al (82) recently performed a meta-analysis to evaluate the pooled sensitivity and specificity of the results of 32 studies, which included 4,172 patients with GC and
2,098 controls. Collectively, the overall sensitivity of DNA methylation-based blood test for detecting GC was 57\% (95\% CI, 50-63\%), while the specificity was 97\% (95\% CI, 95-98\%). The sensitivity and specificity of tests covering multiple methylated genes were $76 \%$ (95\% CI, 64-84\%) and 85\% (95\% CI, $65-95 \%)$, respectively. These results indicate that blood-based DNA methylation tests have high specificity but modest sensitivity for detecting GC. Evaluating multiple methylated genes or using plasma samples seems to improve diagnostic sensitivity.

Besides the methylation markers described above, increased methylation of numerous other genes in cfDNA has also been reported in GC (83-86) (Table V). However, due to the limited sample sizes and method variants, further studies are needed to demonstrate their analytical and clinical validity.

\section{Current challenges}

Although the genetic landscape for GC has been well researched and a large number of candidate biomarkers have been detected in blood samples in the past decades, none of 
these have yet progressed into clinical assays for GC. A number of challenges account for this delay.

First and foremost is the lack of biomarker validation studies demonstrating acceptable sensitivities and specificities for clinical use. In fact, most of the proposed biomarkers were identified or validated in retrospective studies with limited sample sizes. Quantification of plasma cfDNA alone, for example, is insufficient as a clinical biomarker due to its lack of specificity. On the other hand, detection of mutations or rearrangements of ctDNA seems more intriguing due to their biological relevance for tumor initiation and development. However, even the most commonly mutated genes, such as TP53 and KRAS, are typically aberrant in $<50 \%$ of the cases in any particular cancer type. On this context, it is assumed that multigene panel analysis of ctDNA could lead to increased test sensitivity. However, the mutations of these genes are often located in different exons, and their abundance in circulation is generally elevated only in late-stage cancers. This impairs the detection of DNA-based sequence variations, as well as their utility in early cancer detection. For instance, in the recent CancerSEEK study, detecting mutations of 16 genes only achieved $40 \%$ sensitivity for early-stage tumors (38). By contrast, assaying DNA methylation (which is the epigenetic modification of $\mathrm{CpG}$ dinucleotides) is more robust and consistent than testing genetic alterations. There is accumulating evidence that cfDNA gene hypermethylation is more readily detectable than genetic mutations in patients with GC or pre-cancerous diseases such as intestinal metaplasia and dysplasia. For example, the hypermethylation of a number of genes, including RunX3, RPRM and RASSF1A, was significantly elevated in plasma samples of patients with early-stage GC. Aside from Epi proColon, the first FDA-approved gene methylation-based GC assay, Epi proLung, which tests for plasma SHOX2 and PTGER4 gene methylation, recently received a CE-IVD mark in Europe for lung cancer detection as well (87). These developments demonstrate the current utility and future potential of cfDNA methylation assays for cancer detection.

In addition to testing sensitivity and specificity, tracking tumor location is another challenge for cfDNA-based tests. For instance, although hypermethylation of Septin 9 is preferentially detected in patients with CRC, it is also present in some patients with primary lung and stomach cancer $(88,89)$. In fact, even CancerSEEK had to rely on conventional protein tumor biomarkers to track the tissue of origin. However, in patients with early-stage cancer, conventional protein tumor biomarkers can be difficult to detect. Recent studies using computer based-analyses of genome-wide methylation signatures have demonstrated certain potential for identifying the presence, type and location of tumors (90-93). For instance, methylated haplotype load, an analysis of tissue-specific methylation haplotype blocks using whole-genome bisulfite sequencing (WGBS) data, can help to identify cancer-associated biomarkers in both tissue and plasma samples (94). Preliminary data from this analysis demonstrated its potential in determining tissue of origin as well as in predicting cancer development and progression from plasma samples of patients with lung cancer and CRC. Similarly, Kang et al (92) developed CancerLocator, a probabilistic approach to WGBS analysis that is used to predict disease burden and the tissue of origin of ctDNA based on the genome-wide methylation profile of its cfDNA. However, further prospective studies with larger sample sizes are required to validate its utility in clinical settings.

Besides biomarker validation, another challenge for developing cfDNA-based tests in GC is the lack of a standard consensus for experimental procedures, including sampling, storage conditions, cfDNA isolation and enrichment, data analysis and results interpretation (95). Currently, the technologies used for cfDNA detection include qPCR, next-generation sequencing (NGS), dPCR and ultra-sensitive amplification refractory mutation system (ARMS) PCR. Each of these methods has its advantages and drawbacks (96).

Recently, liquid biopsy testing by qPCR (Cobas and Therascreen) was FDA-approved for EGFR exon 19 deletions, EGFR L858R and EGFR T790M in patients with NSCLC. However, these kits have only been validated for allele frequencies of $>1 \%$, which is not sufficient when attempting to detect tumors at early stages (97-99).

By contrast, dPCR has the highest testing sensitivity and suitability in liquid biopsies $(100,101)$. Compared with the characteristics of NGS, dPCR is more cost-effective and has faster turnaround times. However, it has a lower throughput, and can only detect a limited number of known mutations at a time (102). NGS, on the other hand, is theoretically able to detect numerous gene mutations, amplifications and fusions in parallel with higher throughput, and has already been approved for tumor-tissue profiling in the clinic $(103,104)$. Despite this, conventional NGS has relatively low-detection sensitivity and a high-error rate, thus limiting its usefulness for analyzing cfDNA, which occurs in low abundance in plasma samples. New targeted- and genome-wide-NGS approaches for liquid biopsy testing have been developed with improved sensitivity and error-suppression rates $(105,106)$. However, the complicated process, quality control and cost-effectiveness of NGS still need to be improved for clinical applications.

On the other hand, an ultra-sensitive ARMS PCR assay (Udx-PCR, Super-ARMS) was developed, which can detect mutant ctDNA at an allele frequency of $0.1-0.02 \%$ in the background of $10-50 \mathrm{ng}$ wild-type DNA $(46,107)$. This is comparable to the detection sensitivity of dPCR, but with significantly improved robustness, cost-effectiveness and procedural ease.

\section{Conclusion}

Recent milestones in cfDNA analysis as a liquid biopsy for early cancer detection pave the way for its adoption in clinical practice. Among them, Epi proColon is the first population-based CRC screening product that detects gene methylation in plasma samples. Another study led by Chan et al (108) indicated that detection of Epstein-Barr virus DNA in plasma is effective for the screening of early asymptomatic nasopharyngeal carcinoma. Additionally, CancerSEEK has demonstrated how a single assay can screen multiple cancer types by combining ctDNA and protein biomarkers (38). Liquid biopsy draw the attention of independent libraries and commercial companies. In a recent research by GRAIL, which focused on applying cfDNA liquid biopsy to cancer early-stage diagnosis, the sensitivity 
of stage I-III was $67.3 \%$ (CI, 60.7-73.3\%) in a pre-specified set of 12 cancer types (such as anus, bladder, colon/rectum, esophagus, head and neck, liver/bile-duct, lung, lymphoma, ovary, pancreas, plasma cell neoplasm and stomach), and 43.9\% (CI, 39.4-48.5\%) in all cancer types (54). In other studies on breast cancer, 358 cancer and 452 normal cases were included. The results indicated that for three types of breast cancer (triple negative, HER2-positive/hormone receptor-positive and HER2-negative), the sensitivity was 58, 40 and $15 \%$, respectively. This sensitivity shows that cfDNA liquid biopsy is still far from ready-to-use for clinic diagnosis (109). Nonetheless, since non-invasive and low-cost cfDNA testing still plays an important role in consumer-grade cancer diagnosis and cancer treatment management, such as personalized medicine and cancer prognosis. In those studies, two available approaches for early cancer detection using liquid biopsy were presented: i) One assay for one cancer (one-to-one); and ii) one assay for multiple cancer types (one-to-many) by utilizing genome-wide profiling or a large genetic signature panel.

Although numerous potential biomarkers have already been identified in GC, the development of a new generation of minimally invasive cfDNA-based tests for GC early detection must consider their clinical validity and utility. These require collaborative efforts in two areas: i) Developing new assays with improved sensitivity, reproducibility, procedural standardization and cost-effectiveness; and ii) validating emerging biomarkers in larger prospective clinical studies. Although the 'one-to-many' liquid biopsy approach is more attractive in the long term, it presents greater challenges than the 'one-to-one' approach. With these recent advances in cancer genetics and assay modalities, particularly the clinical implementation of circulating methylated DNA-based CRC and lung cancer screening tests, it is expected that a new, clinically effective, liquid biopsy assay for early detection of GC will be available in the near future.

\section{Acknowledgements}

Not applicable.

\section{Funding}

No funding was received.

\section{Availability of data and materials}

Not applicable.

\section{Authors' contributions}

$\mathrm{ZH}$ performed researched data and wrote this manuscript, $\mathrm{HZ}$ contributed to discussions of content and helped to draft the manuscript. BY revised the draft of the manuscript. DY designed the study and revised the manuscript. All authors read and approved the final manuscript.

\section{Ethics approval and consent to participate}

Not applicable.

\section{Patient consent for publication}

Not applicable.

\section{Competing interests}

The authors declare that they have no competing interests.

\section{References}

1. Global Burden of Disease Cancer Collaboration, Fitzmaurice $C$, Allen C, Barber RM, Barregard L, Bhutta ZA, Brenner H, Dicker DJ, Chimed-Orchir O, Dandona R, et al: Global, regional, and national cancer incidence, mortality, years of life lost, years lived with disability, and disability-adjusted life-years for 32 cancer groups, 1990 to 2015: A systematic analysis for the global burden of disease study. JAMA Oncol 3: 524-548, 2017.

2. Karimi P, Islami F, Anandasabapathy S, Freedman ND and Kamangar F: Gastric cancer: Descriptive epidemiology, risk factors, screening, and prevention. Cancer Epidemiol Biomarkers Prev 23: 700-713, 2014.

3. Takahashi T, Saikawa Y and Kitagawa Y: Gastric cancer: Current status of diagnosis and treatment. Cancers (Basel) 5: 48-63, 2013.

4. Orditura M, Galizia G, Sforza V, Gambardella V, Fabozzi A, Laterza MM, Andreozzi F, Ventriglia J, Savastano B, Mabilia A, et al: Treatment of gastric cancer. World J Gastroenterol 20: 1635-1649, 2014

5. Rosati G, Ferrara D and Manzione L: New perspectives in the treatment of advanced or metastatic gastric cancer. World J Gastroenterol 15: 2689-2692, 2009.

6. Hamashima C, Shibuya D, Yamazaki H, Inoue K, Fukao A, Saito $\mathrm{H}$ and Sobue T: The Japanese guidelines for gastric cancer screening. Jpn J Clin Oncol 38: 259-267, 2008.

7. Choi KS, Jun JK, Lee HY, Park S, Jung KW, Han MA, Choi IJ and Park EC: Performance of gastric cancer screening by endoscopy testing through the national cancer screening program of Korea. Cancer Sci 102: 1559-1564, 2011.

8. Leung WK, Wu MS, Kakugawa Y, Kim JJ, Yeoh KG, Goh KL, Wu KC, Wu DC, Sollano J, Kachintorn U, et al: Screening for gastric cancer in Asia: Current evidence and practice. Lancet Oncol 9: 279-287, 2008.

9. Ley C, Mohar A, Guarner J, Herrera-Goepfert R, Figueroa LS, Halperin D and Parsonnet J: Screening markers for chronic atrophic gastritis in Chiapas, Mexico. Cancer Epidemiol Biomarkers Prev 10: 107-112, 2001.

10. Katai $\mathrm{H}$ and Sano T: Early gastric cancer: Concepts, diagnosis, and management. Int J Clin Oncol 10: 375-383, 2005.

11. Tashiro A, Sano M, Kinameri K, Fujita K and Takeuchi Y: Comparing mass screening techniques for gastric cancer in Japan. World J Gastroenterol 12: 4873-4874, 2006.

12. Tonouchi H, Mohri Y, Kobayashi M, Tanaka K, Ohi M and Kusunoki M: Laparoscopy-assisted distal gastrectomy with laparoscopic sentinel lymph node biopsy after endoscopic mucosal resection for early gastric cancer. Surg Endosc 21: 1289-1293, 2007.

13. Kusano C, Iwasaki M, Kaltenbach T, Conlin A, Oda I and Gotoda T: Should elderly patients undergo additional surgery after non-curative endoscopic resection for early gastric cancer? Long-term comparative outcomes. Am J Gastroenterol 106: 1064-1069, 2011

14. ASGE Standards of Practice Committee, Ben-Menachem T, Decker GA, Early DS, Evans J, Fanelli RD, Fisher DA, Fisher L, Fukami N, Hwang JH, et al: Adverse events of upper GI endoscopy. Gastrointest Endosc 76: 707-718, 2012.

15. Mukoubayashi C, Yanaoka K, Ohata H, Arii K, Tamai H, Oka $\mathrm{M}$ and Ichinose M: Serum Pepsinogen and Gastric Cancer Screening. Intern Med 46: 261-266, 2007.

16. Miki K, Ichinose M, Shimizu A, Huang SC, Oka H, Furihata C, Matsushima $T$ and Takahashi K: Serum pepsinogens as a screening test of extensive chronic gastritis. Gastroenterol Jpn 22: 133-141, 1987.

17. Nasrollahzadeh D, Aghcheli K, Sotoudeh M, Shakeri R, Persson EC, Islami F, Kamangar F, Abnet CC, Boffetta P, Engstrand L, et al: Accuracy and cut-off values of pepsinogens I, II and gastrin 17 for diagnosis of gastric fundic atrophy: Influence of gastritis. PLoS One 6: e26957, 2011. 
18. Miki K and Urita Y: Using serum pepsinogens wisely in a clinical practice. J Dig Dis 8: 8-14, 2007.

19. Huang YK, Yu JC, Kang WM, Ma ZQ, Ye X, Tian SB and Yan C: Significance of serum pepsinogens as a biomarker for gastric cancer and atrophic gastritis screening: A systematic review and meta-analysis. PLoS One 10: e0142080, 2015.

20. Zhou J, Ma X, Bi F and Liu M: Clinical significance of circulating tumor cells in gastric cancer patients. Oncotarget 8 25713-25720, 2017.

21. Liu Y, Ling Y, Qi Q, Lan F, Zhu M, Zhang Y, Bao Y and Zhang C: Prognostic value of circulating tumor cells in advanced gastric cancer patients receiving chemotherapy. Mol Clin Oncol 6 : 235-242, 2017.

22. Schwarzenbach H, Hoon DS and Pantel K: Cell-free nucleic acids as biomarkers in cancer patients. Nat Rev Cancer 11: 426-437, 2011.

23. De Mattos-Arruda L, Olmos D and Tabernero J: Prognostic and predictive roles for circulating biomarkers in gastrointestinal cancer. Future Oncol 7: 1385-1397, 2011.

24. Shapiro B,Chakrabarty M,CohnEM and Leon SA: Determination of circulating DNA levels in patients with benign or malignant gastrointestinal disease. Cancer 51: 2116-2120, 1983

25. Sai S, Ichikawa D, Tomita H, Ikoma D, Tani N, Ikoma H, Kikuchi S, Fujiwara H, Ueda Y and Otsuji E: Quantification of plasma cell-free DNA in patients with gastric cancer. Anticancer Res 27: 2747-2751, 2007.

26. Park JL, Kim HJ, Choi BY, Lee HC, Jang HR, Song KS, Noh SM, Kim SY, Han DS and Kim YS: Quantitative analysis of cell-free DNA in the plasma of gastric cancer patients. Oncol Lett 3 921-926, 2012 .

27. Kim K, Shin DG, Park MK, Baik SH, Kim TH, Kim S and Lee S Circulating cell-free DNA as a promising biomarker in patients with gastric cancer: Diagnostic validity and significant reduction of cfDNA after surgical resection. Ann Surg Treat Res 86: $136-142,2014$

28. Qian C, Ju S, Qi J, Zhao J, Shen X, Jing R, Yu J, Li L, Shi Y, Zhang L, et al: Alu-based cell-free DNA: A novel biomarker for screening of gastric cancer. Oncotarget 8: 54037-54045, 2016.

29. Kolesnikova EV, Tamkovich SN, Bryzgunova OE, Shelestyuk PI Permyakova VI, Vlassov VV, Tuzikov AS, Laktionov PP and Rykova EY: Circulating DNA in the blood of gastric cancer patients. Ann N Y Acad Sci 1137: 226-231, 2008.

30. Coimbra S, Catarino C, Costa E, Oliveira H, Figueiredo A Rocha-Pereira P and Santos-Silva A: Circulating cell-free DNA levels in Portuguese patients with psoriasis vulgaris according to severity and therapy. Br J Dermatol 170: 939-942, 2014.

31. Chen C, Shi C, Huang X, Zheng J, Zhu Z, Li Q, Qiu S, Huang Z, Zhuang $\mathrm{Z}, \mathrm{Wu} \mathrm{R}$, et al: Molecular profiles and metastasis markers in Chinese patients with gastric carcinoma. Sci Rep 9: 13995, 2019.

32. Wu R, Li Q, Wu F, Shi C and Chen Q: Comprehensive analysis of CDC27 related to peritoneal metastasis by whole exome sequencing in gastric cancer. Onco Targets Ther 13: 3335-3346, 2020.

33. Wang R, Song S, Harada K, Ghazanfari Amlashi F, Badgwell B, Pizzi MP, Xu Y, Zhao W, Dong X, Jin J, et al: Multiplex profiling of peritoneal metastases from gastric adenocarcinoma identified novel targets and molecular subtypes that predict treatment response. Gut 69: 18-31, 2020.

34. Leon SA, Shapiro B, Sklaroff DM and Yaros MJ: Free DNA in the serum of cancer patients and the effect of therapy. Cancer Res 37: 646-650, 1977.

35. Chen K, Zhao H, Yang F, Hui B, Wang T, Wang LT, Shi Y and Wang J: Dynamic changes of circulating tumour DNA in surgical lung cancer patients: Protocol for a prospective observational study. BMJ Open 8: e019012, 2018.

36. Bachet JB, Bouché O, Taieb J, Dubreuil O, Garcia ML Meurisse A, Normand C, Gornet JM, Artru P, Louafi S, et al: RAS mutation analysis in circulating tumor DNA from patients with metastatic colorectal cancer: The AGEO RASANC prospective multicenter study. Ann Oncol 29: 1211-1219, 2018

37. Bettegowda C, Sausen M, Leary RJ, Kinde I, Wang Y, Agrawal N, Bartlett BR, Wang H, Luber B, Alani RM, et al: Detection of circulating tumor DNA in early- and late-stage human malignancies. Sci Transl Med 6: 224ra24, 2014.

38. Cohen JD, Li L, Wang Y, Thoburn C, Afsari B, Danilova L, Douville C, Javed AA, Wong F, Mattox A, et al: Detection and localization of surgically resectable cancers with a multi-analyte blood test. Science 359: 926-930, 2018.
39. Deng N, Goh LK, Wang H, Das K, Tao J, Tan IB, Zhang S, Lee M, Wu J, Lim KH, et al: A comprehensive survey of genomic alterations in gastric cancer reveals systematic patterns of molecular exclusivity and co-occurrence among distinct therapeutic targets. Gut 61: 673-684, 2012

40. Qian Z, Zhu G, Tang L, Wang M, Zhang L, Fu J, Huang C, Fan S, Sun Y, Lv J, et al: Whole genome gene copy number profiling of gastric cancer identifies PAK1 and KRAS gene amplification as therapy targets. Genes Chromosomes Cancer 53: 883-894, 2014.

41. Park KU, Lee HE, Park DJ, Jung EJ, Song J, Kim HH, Choe G, Kim WH and Lee HS: MYC quantitation in cell-free plasma DNA by real-time PCR for gastric cancer diagnosis. Clin Chem Lab Med 47: 530-536, 2009.

42. Park KU, Lee HE, Nam SK, Nam KH, Park DJ, Kim HH, Kim WH and Lee HS: The quantification of HER2 and MYC gene fragments in cell-free plasma as putative biomarkers for gastric cancer diagnosis. Clin Chem Lab Med 52: 1033-1040, 2014.

43. Kinugasa H, Nouso K, Tanaka T, Miyahara K, Morimoto Y, Dohi C, Matsubara T, Okada H and Yamamoto K: Droplet digital PCR measurement of HER2 in patients with gastric cancer. Br J Cancer 112: 1652-1655, 2015.

44. Shoda K, Ichikawa D, Fujita Y, Masuda K, Hiramoto H,Hamada J, Arita T, Konishi H, Komatsu S, Shiozaki A, et al: Monitoring the HER 2 copy number status in circulating tumor DNA by droplet digital PCR in patients with gastric cancer. Gastric Cancer 20: 126-135, 2017.

45. Taby R and Issa JP: Cancer epigenetics. CA Cancer J Clin 60: 376-392, 2010.

46. Li Y, Xu H, Su S, Ye J, Chen J, Jin X, Lin Q, Zhang D, Ye C and Chen C: Clinical validation of a highly sensitive assay to detect EGFR mutations in plasma cell-free DNA from patients with advanced lung adenocarcinoma. PLoS One 12: e0183331, 2017.

47. Baylin SB, Herman JG, Graff JR, Vertino PM and Issa JP: Alterations in DNA methylation: A fundamental aspect of neoplasia. Adv Cancer Res 72: 141-196, 1998.

48. Jones PA and Laird PW: Cancer-epigenetics comes of age. Nat Genet 21: 163-167, 1999.

49. Ebrahimi V, Soleimanian A, Ebrahimi T, Azargun R, Yazdani P, Eyvazi $\mathrm{S}$ and Tarhriz V: Epigenetic modifications in gastric cancer: Focus on DNA methylation. Gene 742: 144577, 2020.

50. Eyvazi S, Khamaneh AM, Tarhriz V, Bandehpour M, Hejazi MS Sadat ATE and Sepehri B: CpG islands methylation analysis of CDH11, EphA5, and HS3ST2 genes in gastric adenocarcinoma patients. J Gastrointest Cancer 51: 579-583, 2020.

51. Donaldson J and Park BH: Circulating tumor DNA: Measurement and clinical utility. Annu Rev Med 69: 223-234, 2018

52. Chen X, Gole J, Gore A, He Q, Lu M, Min J, Yuan Z, Yang X, Jiang Y, Zhang T, et al: Non-invasive early detection of cancer four years before conventional diagnosis using a blood test. Nat Commun 11: 3475, 2020.

53. Jiang P, Chan KCA and Lo YMD: Liver-derived cell-free nucleic acids in plasma: Biology and applications in liquid biopsies. J Hepatol 71: 409-421, 2019.

54. Liu MC, Oxnard GR, Klein EA, Swanton C, Seiden MV, Liu MC, Oxnard GR, Klein EA, Smith D, Richards D et al: Sensitive and specific multi-cancer detection and localization using methylation signatures in cell-free DNA. Ann Oncol 31: 745-759, 2020.

55. U.S. Food and Drug Administration (FDA): Premarket Approval (PMA) for Epi ProColon. FDA, Silver Spring, MD, 2016.

56. Bennett KL, Karpenko M,Lin MT, Claus R, Arab K, Dyckhoff G, Plinkert P, Herpel E, Smiraglia D and Plass C: Frequently methylated tumor suppressor genes in head and neck squamous cell carcinoma. Cancer Res 68: 4494-4499, 2008

57. Kreuziger LM, Porcher JC, Ketterling RP and Steensma DP An MLL-SEPT9 fusion and $\mathrm{t}(11 ; 17)(\mathrm{q} 23 ; \mathrm{q} 25)$ associated with de novo myelodysplastic syndrome. Leuk Res 31: 1145-1148, 2007.

58. Shirley M: Epi proColon ${ }^{\circledR}$ for colorectal cancer screening: A profile of its use in the USA. Mol Diagn Ther 24: 497-503, 2020.

59. Church TR, Wandell M, Lofton-Day C, Mongin SJ, Burger M, Payne SR, Castaños-Vélez E, Blumenstein BA, Rösch T, Osborn N, et al: Prospective evaluation of methylated SEPT9 in plasma for detection of asymptomatic colorectal cancer. Gut 63 : 317-325, 2014.

60. Nian J, Sun X, Ming S, Yan C, Ma Y, Feng Y, Yang L, Yu M, Zhang $G$ and Wang X: Diagnostic accuracy of methylated SEPT9 for blood-based colorectal cancer detection: A systematic review and meta-analysis. Clin Transl Gastroenterol 8: e216, 2017. 
61. Cai L, Hood S, Kallam E, Overman D, Barker K, Rutledge D, Riojas J, Best C, Eisenberg M, and Kam-Morgan L: Epi proColon ${ }^{\circledR}$ : Use of a non-invasive SEPT9 gene methylation blood test for colorectal cancer screening: A national laboratory experience. J Clin Epigenet 4: 7, 2018.

62. Sherr CJ: The pezcoller lecture: Cancer cell cycles revisited. Cancer Res 60: 3689-3695, 2000.

63. Weisenberger DJ: Characterizing DNA methylation alterations from the cancer genome atlas. J Clin Invest 124: 17-23, 2014.

64. Kanyama Y, Hibi K, Nakayama H, Kodera Y, Ito K, Akiyama S and Nakao A: Detection of p16 promoter hypermethylation in serum of gastric cancer patients. Cancer Sci 94: 418-420, 2003.

65. Ichikawa D, Koike H, Ikoma H, Ikoma D, Tani N, Otsuji E, Kitamura K and Yamagishi H: Detection of aberrant methylation as a tumor marker in serum of patients with gastric cancer. Anticancer Res 24: 2477-2481, 2004

66. Guo L, Huang C and Ji QJ: Aberrant promoter hypermethylation of p16, survivin, and retinoblastoma in gastric cancer. Bratisl Lek Listy 118: 164-168, 2017.

67. Abbaszadegan MR, Moaven O, Sima HR, Ghafarzadegan K, A'Rabi A, Forghani MN, Raziee HR, Mashhadinejad A, Jafarzadeh M, Esmaili-Shandiz E and Dadkhah E: p16 promoter hypermethylation: A useful serum marker for early detection of gastric cancer. World J Gastroenterol 14: 2055-2060, 2008.

68. Chen F, Liu X, Bai J, Pei D and Zheng J: The emerging role of RUNX3 in cancer metastasis (Review). Oncol Rep 35: 1227-1236, 2016.

69. Kim TY, Lee HJ, Hwang KS, Lee M, Kim JW, Bang YJ and Kang GH: Methylation of RUNX3 in various types of human cancers and premalignant stages of gastric carcinoma. Lab Invest 84: 479-484, 2004

70. Sakakura C, Hamada T, Miyagawa K, Nishio M, Miyashita A, Nagata H, Ida H, Yazumi S, Otsuji E, Chiba T, et al: Quantitative analysis of tumor-derived methylated RUNX3 sequences in the serum of gastric cancer patients. Anticancer Res 29: 2619-2625, 2009.

71. Lu XX, Yu JL, Ying LS, Han J, Wang S, Yu QM, Wang XB, Fang XH and Ling ZQ: Stepwise cumulation of RUNX3 methylation mediated by Helicobacter pylori infection contributes to gastric carcinoma progression. Cancer 118: 5507-5517, 2012.

72. Lin Z, Luo M, Chen X, He X, Qian Y, Lai S, Si J and Chen S: Combined detection of plasma ZIC1, HOXD10 and RUNX3 methylation is a promising strategy for early detection of gastric cancer and precancerous lesions. J Cancer 8: 1038-1044, 2017.

73. Shi DT, Han M, Gao N, Tian W and Chen W: Association of RASSF1A promoter methylation with gastric cancer risk: A meta-analysis. Tumour Biol 35: 943-948, 2014.

74. Wang YC, Yu ZH, Liu C, Xu LZ, Yu W, Lu J, Zhu RM, Li GL, Xia XY, Wei XW, et al: Detection of RASSF1A promoter hypermethylation in serum from gastric and colorectal adenocarcinoma patients. World J Gastroenterol 14: 3074-3080, 2008

75. Balgkouranidou I, Matthaios D, Karayiannakis A, Bolanaki H, Michailidis P, Xenidis N, Amarantidis K, Chelis L, Trypsianis G, Chatzaki E, et al: Prognostic role of APC and RASSF1A promoter methylation status in cell free circulating DNA of operable gastric cancer patients. Mutat Res 778: 46-51, 2015.

76. Pimson C, Ekalaksananan T, Pientong C, Promthet S, Putthanachote N, Suwanrungruang K and Wiangnon S: Aberrant methylation of PCDH10 and RASSF1A genes in blood samples for non-invasive diagnosis and prognostic assessment of gastric cancer. PeerJ 4: e2112, 2016.

77. Ohki R, Nemoto J, Murasawa H, Oda E, Inazawa J, Tanaka N and Taniguchi T: Reprimo, a new candidate mediator of the p53-mediated cell cycle arrest at the G2 phase. J Biol Chem 275 : 22627-22630, 2000

78. Ooki A, Yamashita K, Yamaguchi K, Mondal A, Nishimiya H and Watanabe M: DNA damage-inducible gene, Reprimo functions as a tumor-suppressor and is suppressed by promoter methylation in gastric cancer. Mol Cancer Res 11: 1362-1374, 2013.

79. Bernal C, Aguayo F, Villarroel C, Vargas M, Díaz I, Ossandon FJ, Santibáñez E, Palma M, Aravena E, Barrientos C and Corvalan $\mathrm{AH}$ : Reprimo as a potential biomarker for early detection in gastric cancer. Clin Cancer Res 14: 6264-6269, 2008

80. Liu L and Yang X: Implication of Reprimo and hMLH1 gene methylation in early diagnosis of gastric carcinoma. Int J Clin Exp Pathol 8: 14977-14982, 2015.

81. Lai J, Wang H, Luo Q, Huang S, Lin S, Zheng Y and Chen Q: The relationship between DNA methylation and Reprimo gene expression in gastric cancer cells. Oncotarget 8: 108610-108623, 2017
82.Hu W, Zheng W, Liu Q, Chu H, Chen S, Kim JJ, Wu J and Si J: Diagnostic accuracy of DNA methylation in detection of gastric cancer: A meta-analysis. Oncotarget 8: 113142-113152, 2015.

83. Chen X, Lin Z, Xue M, Si J and Chen S: Zic1 promoter hypermethylation in plasma DNA is a potential biomarker for gastric cancer and intraepithelial neoplasia. PLoS One 10: e0133906, 2015.

84. Xue WJ, Feng Y, Wang F, Li P, Liu YF, Guo YB, Wang ZW and Mao QS: The value of serum RASSF10 hypermethylation as a diagnostic and prognostic tool for gastric cancer. Tumour Biol 37: 11249-11257, 2016.

85. Cheung KF, Lam CN, Wu K, Ng EK, Chong WW, Cheng AS, To KF, Fan D, Sung JJ and Yu J: Characterization of the gene structure, functional significance, and clinical application of RNF180, a novel gene in gastric cancer. Cancer 118: 947-959, 2012.

86. Liu C, Li N, Lu H, Wang Z, Chen C, Wu L, Liu J, Lu Y and Wang F: Circulating SFRP1 promoter methylation status in gastric adenocarcinoma and esophageal square cell carcinoma. Biomed Rep 3: 123-127, 2015.

87. epigenomics: Epigenomics AG gets CE-IVD Mark for Lung Cancer Test Epi proLung(R), 2017.

88. Powrózek T, Krawczyk P, Kucharczyk T and Milanowski J: Septin 9 promoter region methylation in free circulating DNA-potential role in noninvasive diagnosis of lung cancer: Preliminary report. Med Oncol 31: 917, 2014.

89. Lee HS, Hwang SM, Kim TS, Kim DW, Park DJ, Kang SB, Kim HH and Park KU: Circulating methylated septin 9 nucleic Acid in the plasma of patients with gastrointestinal cancer in the stomach and colon. Transl Oncol 6: 290-296, 2013.

90. Lehmann-Werman R, Neiman D, Zemmour H, Moss J, Magenheim J, Vaknin-Dembinsky A, Rubertsson S, Nellgård B, Blennow $\mathrm{K}$, Zetterberg $\mathrm{H}$, et al: Identification of tissue-specific cell death using methylation patterns of circulating DNA. Proc Natl Acad Sci USA 113: E1826-E1834, 2016.

91. Snyder MW, Kircher M, Hill AJ, Daza RM and Shendure J: Cell-free DNA comprises an in vivo nucleosome footprint that informs its tissues-of-origin. Cell 164: 57-68, 2016.

92.Kang S, Li Q, Chen Q, Zhou Y, Park S, Lee G, Grimes B, Krysan K, Yu M, Wang W, et al: CancerLocator: Non-invasive cancer diagnosis and tissue-of-origin prediction using methylation profiles of cell-free DNA. Genome Biol 18: 53, 2017.

93. Guo S, Diep D, Plongthongkum N, Fung HL, Zhang K and Zhang K: Identification of methylation haplotype blocks aids in deconvolution of heterogeneous tissue samples and tumor tissue-of-origin mapping from plasma DNA. Nat Genet 49: 635-642, 2017

94. Wan JCM, Massie C, Garcia-Corbacho J, Mouliere F, Brenton JD, Caldas C, Pacey S, Baird R and Rosenfeld N: Liquid biopsies come of age: Towards implementation of circulating tumour DNA. Nat Rev Cancer 17: 223-238, 2017.

95. Heitzer E, Haque IS, Roberts CES and Speicher MR: Current and future perspectives of liquid biopsies in genomics-driven oncology. Nat Rev Genet 20: 71-88, 2019.

96. Leung F, Kulasingam V, Diamandis EP, Hoon DS, Kinzler K, Pantel $\mathrm{K}$ and Alix-Panabières C: Circulating tumor DNA as a cancer biomarker: Fact or fiction? Clin Chem 62: 1054-1060, 2016.

97. Bartels S, Persing S, Hasemeier B, Schipper E, Kreipe H and Lehmann U: Molecular analysis of circulating cell-free DNA from lung cancer patients in routine laboratory practice: A cross-platform comparison of three different molecular methods for mutation detection. J Mol Diagn 19: 722-732, 2017.

98. Wan R, Wang Z, Lee JJ, Wang S, Li Q, Tang F, Wang J, Sun Y, Bai H, Wang D, et al: Comprehensive analysis of the discordance of EGFR mutation status between tumor tissues and matched circulating tumor DNA in advanced non-small cell lung cancer. J Thorac Oncol 12: 1376-1387, 2017.

99. Guttery DS, Page K, Hills A, Woodley L, Marchese SD, Rghebi B, Hastings RK, Luo J, Pringle JH, Stebbing J, et al: Noninvasive detection of activating estrogen receptor 1 (ESR 1 ) mutations in estrogen receptor-positive metastatic breast cancer. Clin Chem 61: 974-982, 2015.

100. Busser B, Lupo J, Sancey L, Mouret S, Faure P, Plumas J, Chaperot L, Leccia MT, Coll JL, Hurbin A, et al: Plasma circulating tumor DNA levels for the monitoring of melanoma patients: Landscape of available technologies and clinical applications. Biomed Res Int 2017: 5986129, 2017. 
101. Rachiglio AM, Esposito Abate R, Sacco A, Pasquale R, Fenizia F, Lambiase M, Morabito A, Montanino A, Rocco G, Romano C, et al: Limits and potential of targeted sequencing analysis of liquid biopsy in patients with lung and colon carcinoma. Oncotarget 7: 66595-66605, 2016.

102. Xu S, Lou F, Wu Y, Sun DQ, Zhang JB, Chen W, Ye H, Liu JH, Wei S, Zhao MY, et al: Circulating tumor DNA identified by targeted sequencing in advanced-stage non-small cell lung cancer patients. Cancer Lett 370: 324-331, 2016.

103. Newman AM, Lovejoy AF, Klass DM, Kurtz DM, Chabon JJ, Scherer F, Stehr H, Liu CL, Bratman SV, Say C, et al: Integrated digital error suppression for improved detection of circulating tumor DNA. Nat Biotechnol 34: 547-555, 2016.

104. Phallen J, Sausen M, Adleff V, Leal A, Hruban C, White J, Anagnostou V, Fiksel J, Cristiano S, Papp E, et al: Direct detection of early-stage cancers using circulating tumor DNA. Sci Transl Med 9: eaan2415, 2017.

105. Belic J, Koch M, Ulz P, Auer M, Gerhalter T, Mohan S, Fischereder K, Petru E, Bauernhofer T, Geigl JB, et al: Rapid identification of plasma DNA samples with increased ctDNA levels by a modified FAST-SeqS approach. Clin Chem 61: 838-849, 2015.

106. Kinde I, Wu J, Papadopoulos N, Kinzler KW and Vogelstein B: Detection and quantification of rare mutations with massively parallel sequencing. Proc Natl Acad Sci USA 108: 9530-9535, 2011

107. Zhai J, Wu Y, Luo X, Li X and Yu DH: Abstract 643: An ultra-sensitive multiplex allele-specific real-time PCR (Udx-PCR) assay for detection of KRAS BRAF NRAS mutations in colorectal cancer. Cancer Res 78: 643, 2018.

108. Chan KCA, Woo JKS, King A, Zee BCY, Lam WKJ, Chan SL, Chu SWI, Mak C, Tse IOL, Leung SYM, et al: Analysis of plasma epstein-barr virus DNA to screen for nasopharyngeal cancer. N Engl J Med 377: 513-522, 2017.

109. Fiala C and Diamandis EP: Can Grail find the trail to early cancer detection? Clin Chem Lab Med 57: 403-406, 2019.

110. Liu YH, Zhang LH, Ren H, Zhang GG, Qin F, Kong GZ, Deng GR and Ji JF: Promoter hypermethylation of p16 gene in pre- and post-operative plasma of patients with gastric adenocarcinoma. Beijing Da Xue Xue Bao Yi Xue Ban 37: 257-260, 2005 (In Chinese).

111. Koike H, Ichikawa D, Ikoma H, Otsuji E, Kitamura K and Yamagishi H: Comparison of methylation-specific polymerase chain reaction (MSP) with reverse transcriptase-polymerase chain reaction (RT-PCR) in peripheral blood of gastric cancer patients. J Surg Oncol 87: 182-186, 2004.

112. Guo X, Liu W, Pan Y, Ni P, Ji J, Guo L, Zhang J, Wu J, Jiang J, Chen X, et al: Homeobox gene IRX1 is a tumor suppressor gene in gastric carcinoma. Oncogene 29: 3908-3920, 2010.
113. Zheng Y, Chen L, Li J, Yu B, Su L, Chen X, Yu Y, Yan M, Liu B and Zhu Z: Hypermethylated DNA as potential biomarkers for gastric cancer diagnosis. Clin Biochem 44: 1405-1411, 2011.

114. Ng EK, Leung CP, Shin VY, Wong CL, Ma ES, Jin HC, Chu KM and Kwong A: Quantitative analysis and diagnostic significance of methylated SLC19A3 DNA in the plasma of breast and gastric cancer patients. PLoS One 6: e22233, 2011

115. Chen L, Su L, Li J, Zheng Y, Yu B, Yu Y, Yan M, Gu Q, Zhu Z and Liu B: Hypermethylated FAM5C and MYLK in serum as diagnosis and pre-warning markers for gastric cancer. Dis Markers 32: 195-202, 2012.

116. Raja UM, Gopal G and Rajkumar T: Intragenic DNA methylation concomitant with repression of ATP4B and ATP4A gene expression in gastric cancer is a potential serum biomarker. Asian Pac J Cancer Prev 13: 5563-5568, 2012.

117. Ling ZQ, Lv P, Lu XX, Yu JL, Han J, Ying LS, Zhu X, Zhu WY, Fang XH, Wang $\mathrm{S}$ and Wu YC: Circulating methylated XAF1 DNA indicates poor prognosis for gastric cancer. PLoS One 8: e67195, 2013.

118. Balgkouranidou I, Karayiannakis A, Matthaios D, Bolanaki H, Tripsianis G, Tentes AA, Lianidou E, Chatzaki E, Fiska A, Lambropoulou M, et al: Assessment of SOX17 DNA methylation in cell free DNA from patients with operable gastric cancer. Association with prognostic variables and survival. Clin Chem Lab Med 51: 1505-1510, 2013.

119. Zhang H, Song Y, Xia P, Cheng Y, Guo Q, Diao D, Wang W, Wu X, Liu D and Dang C: Detection of aberrant hypermethylated spastic paraplegia-20 as a potential biomarker and prognostic factor in gastric cancer. Med Oncol 31: 830, 2014.

120. Wang G, Zhang W, Zhou B, Jin C, Wang Z, Yang Y, Wang Z, Chen $\mathrm{Y}$ and Feng $\mathrm{X}$ : The diagnosis value of promoter methylation of UCHL1 in the serum for progression of gastric cancer. Biomed Res Int 2015: 741030, 2015

121. Li WH, Zhou ZJ, Huang TH, Guo K, Chen W, Wang Y, Zhang H, Song YC and Chang DM: Detection of OSR2, VAV3, and PPFIA3 methylation in the serum of patients with gastric cancer. Dis Markers 2016: 5780538, 2016.

122. Hu H, Chen X, Wang C, Jiang Y, Li J, Ying X, Yang Y, Li B, Zhou C, Zhong J, et al: The role of TFPI2 hypermethylation in the detection of gastric and colorectal cancer. Oncotarget 8 : 84054-84065, 2017. 